\title{
Influence of Seasonality on Buffalo Semen
}

\author{
Sâmia Rubielle Silva de Castro ${ }^{1,3}$, , Adriana Caroprezzo Morini ${ }^{1}$, \\ Alanna do Socorro Lima da Silva ${ }^{1}$, Kedson Alessandri Lobo Neves ${ }^{1,2,3}$, \\ Antônio Humberto Hamad Minervino ${ }^{1,2,3}$, Anderson Alvarenga de Moura Meneses ${ }^{2,3}$, \\ William Gomes Vale ${ }^{1,2,3}$ \\ ${ }^{1}$ Laboratory Animal Biotechnology, Institute of Biodiversity and Forests (IBEF), Federal University of Western Pará, Santarém, Brazil \\ ${ }^{2}$ Institute of Geosciences and Engineering (IEG), Federal University of Western Pará, Santarém, Brazil \\ ${ }^{3}$ Postgraduate Program in Society, Nature and Development (SND), Federal University of Western Pará, Santarém, Brazil
}

\section{Email address:}

samiarubielle@hotmail.com (S. R. S. de Castro)

${ }^{*}$ Corresponding author

\section{To cite this article:}

Sâmia Rubielle Silva de Castro, Adriana Caroprezzo Morini, Alanna do Socorro Lima da Silva, Kedson Alessandri Lobo Neves, Antônio Humberto Hamad Minervino, Anderson Alvarenga de Moura Meneses, William Gomes Vale. Influence of Seasonality on Buffalo Semen. Animal and Veterinary Sciences. Vol. 5, No. 3, 2017, pp. 45-51. doi: 10.11648/j.avs.20170503.12

Received: March 21, 2017; Accepted: April 18, 2017; Published: June 23, 2017

\begin{abstract}
The present study was undertaken with the objective to compare the influence of seasonal temperature variations on parameters of ejaculates of Murrah buffalo bulls raised in the humid tropical Amazonian climate. Five buffaloes were selected from a batch of 12 adult bulls, pre-evaluated for clinical and andrological examination, and were used as semen donors, using as criterion the best ejaculate quality. The objective of the present study was, therefore, to test the hypothesis that season affects buffalo semen quality in tropical regions. The experimental period was divided into two phases: rainy season (RS), from February to May, and non rainy season (nRS), from August to November 2016. The ejaculates were collected twice a week $(n=30)$ per bull, namely 10 ejaculates in the RS and 20 ejaculates in the nRS period, totaling $(n=150)$ samples for analysis. The evaluations of the semen samples were performed with fresh semen, immediately after each collection. The immediate analyzes pertinent to the physical and morphological characteristics of the ejaculates showed that a significant statistical difference was observed for the parameters wave motion, motility, vigor, major defects, minor defects, total defects and plasma membrane integrity between the both periods $(\mathrm{P}<0.05)$. In the mesoregion of the Lower Amazon, a tropical region, the ideal period for experiments using buffalo ejaculates, are the months of the rainy season. For in this period a better quality without ejaculate of buffaloes was observed.
\end{abstract}

Keywords: Amazon, Environment, Reproductive Parameters, Tropical Region, Season

\section{Introduction}

In recent years the study of the influence of the environment on animal production has become important [1, $2,3]$. Buffaloes are homeothermic animals and, as such, are able to maintain their body temperature within a wide range, using some physiological and behavioural mechanisms that aid in thermoregulation. As buffaloes are raised in different climatic environments, such aspects provide this species the ability to adapt to diverse ecosystems. Ambient temperature is one of the climatic factors with the greatest influence on the physical environment in which the animal is found $[4,5]$.

Due the fact that sexual behaviour depends directly on the production of hormones, especially those produced by the pituitary-gonads and adrenal axis, the hormonal secretion of these endocrine glands can be suppressed when some stressor agent acts. Thus, males subjected to thermal stress have their sexual activity depressed, with less testosterone production, due to the production of stressors secreted by metabolism [1, $6,7,8,9,10]$.

In general, stress can be defined as any factor or change from the environment which interferes with homeostasis, which is a complex and dynamic system of equilibrium that governs the correct functioning of living organisms. Stress 
prevents animals from expressing their full genetic potential, leading to reduced performance and detrimental reproductive efficiency $[3,10]$. In addition, among the factors that cause imbalance of homeostasis, the most important are diseases, nutritional deprivation, incorrect handling of the herd, transportation and thermal stress, either by cold or heat [11, 33]. The ideal climatic conditions for the development and reproduction of buffaloes are considered to be ambient temperature between $13^{\circ}$ and $18^{\circ} \mathrm{C}$, associated with average relative humidity between 55 and $65 \%$ medium intensity sunshine and wind speed between 5 and $8 \mathrm{Km} / \mathrm{h}$ [11]. Thus, based on the climatic characteristics of the countries where the great majority of buffalo contingents are raised, it can be assumed that the real problem of buffalo production systems in tropical areas seems to be related to the heat caused by thermal stress [5].

Similarly, it has been reported that buffaloes have difficulty in dissipating body heat, due to having a black pelt with a high content of melanin and lower amount of sweat glands [1, 12]. Furthermore, there is always the need for access to shade and water. Thus, good measures to maintain homeostasis include, firstly, preventing the animals from being exposed directly to intense solar radiation and, subsequently, facilitating the mechanisms of heat loss to the environment. In both cases, human intervention with management practices have shown positive results $[1,12]$.

Likewise, in males, thermal stress results in reduced seminal quality and lower viability of sperm [1, 3, 13]. Therefore, in much of Brazilian environmental conditions, especially in the humid tropical climate of the Amazon region, environmental management practices associated with animal management are fundamental for the sustainability of the buffalo production system [8].

Considering that the buffalo species presents reproductive seasonality, the variation in seminal quality may occur as a function of the season, with a greater reproductive activity in the autumn / winter seasons, which present the short days (hour $\mathrm{x}$ light) $[10,13]$. This variation occurs even in relation to testosterone, which surprisingly, in the literature consulted, shows lower blood concentrations in autumn and winter, which are the breeding seasons of buffalo, rather than in spring and summer [14]. That being so, in regions where there are well-defined seasons during the year, it should be considered if there is any seasonal influence on seminal quality in this species [14]. Therefore, in the tropical humid Amazon rainforest environment, where climate is characterized by rainy and non-rainy periods, and the temperature and relative humidity remain very high throughout the year, causing discomfort and thermal stress in farm animals, especially in buffalo, further studies were necessary to elucidate the real condition existing at local level $[5,8]$.

Thus, the present study aims to evaluate the influence of the seasonal variation on the reproductive parameters of buffaloes semen reared in the humid tropical Amazonian climate.

\section{Material and Methods}

\subsection{Study Area}

The municipality of Santarém belongs to the mesoregion of the Lower Amazon and is located at geographic coordinates $02^{\circ} 26^{\prime} 35^{\prime \prime} \mathrm{S} ; 54^{\circ} 42^{\prime} 30^{\prime \prime} \mathrm{W}$, and is distant 1,520 $\mathrm{km}$ from Belém city, the capital of Pará State. The predominant vegetation cover of the landscape is the equatorial broadleaf forest, and there are also large areas of savannah. The main river of the municipality is the Tapajós which crosses it in a South-North direction, ending on the right bank of the Amazon River in front of the city. Flood plain areas are predominant on the riverbanks and play an important role for the region's buffalo and cattle production systems. The air temperature is always high, with an annual average of $25.6{ }^{\circ} \mathrm{C}$, and the relative humidity of the air is above $80 \%$ during almost every month of the year. Rainfall averages $2,000 \mathrm{~mm}$ per year, however, it is characterized by a certain irregularity of rainfall between the months of July and November, with the rainy season coinciding with the months of December to June [15].

In order to characterize the study area, a mini-station (WSGP1 Weather Station, AT Delta-Devices Ltd) was installed at the experiment site to measure ambient temperature $\left({ }^{\circ} \mathrm{C}\right)$, relative humidity, rainfall, solar radiation $\left(\mathrm{Wm}^{-2}\right)$ and wind speed $\left(\mathrm{ms}^{-1}\right)$. The mini-station was located inside the bull stalls where the sires were kept. Owing to distinct mean levels of ambient temperature, rainfall and humidity, for the purpose of the present study the year was divided into two seasons, namely (i) the rainy season (RS and (ii) non rainy season (nRS), corresponding to December-June through JulyNovember, respectively.

\subsection{Study Area and Animals}

The experiment was carried out in the municipality of Santarém, western Pará state, in the Agricultural Exposition Park of the Rural Syndicate of Santarém. Twelve adult bulls of the Murrah breed were randomly selected from a herd of more than 200 and from these 12 bulls 5 were selected to be sperm donors based on the highest score in a clinical and andrological examination using as criterion the best ejaculate quality. Donors age and body weight average was $2.5 \pm 0.5$ years $450.0 \pm 35.5 \mathrm{~kg}$ at the beginning of the experiment, respectively. The animals were kept in a confinement regime, separated into individual stalls and fed with the grass Echinochloa polystachya (Canarana-de-pico) ad libitum and supplemented with two $\mathrm{kg}$ of a feed composed by corn, soy and sorghum and mineral salt. The animals had constant access to fresh and clean water, as well as mineral salt ad libitum in a trough. The sanitary control (anthelmintic and vitamin supplementation) was carried out according to preestablished criteria for the species, as well as vaccination against foot-and-mouth disease and testing for brucellosis and tuberculosis.

The experimental period was divided into two phases: rainy season (RS), from February to May, and the non rainy 
season (nRS), from August to November 2016. The ejaculates were collected twice a week between 06:00 and 07:00 AM. Prior to each collection, the animals received a shower on whole body and the preputial sac was cleaned, and then the bulls were taken to the female in heat that was immobilized in an individual stall.

Semen collections were performed using a medium length artificial vagina method, using a Minitub model (Germany). Ejaculates $(n=30)$ per bull, namely $(n=10)$ in the $R S$ and $(n=20)$ ejaculates in the $n R S$ period, totaling $(n=150)$ samples for analysis, were processed according to the methodology recommended for buffalo by $[6,16]$. Seminal processing and laboratory analyzes were performed at the Animal Biotechnology Laboratory of the Federal University of the West of Pará.

The evaluations of the semen samples were performed with fresh semen, immediately after each collection. The immediate analyzes carried out were pertinent to the physical and morphological characteristics of the ejaculates, and corresponded to the measurement of volume, colour, appearance, mass activity (swirling), concentration of ejaculate, progressive motility, vigour, evaluation of plasma membrane integrity and sperm morphology $[6,17]$.

The volume of the semen obtained in the samples was measured in a volumetric tube $(\mathrm{mL})$, while the colour and appearance were evaluated in a visual scale [16], and the mass activity was evaluated by the sample of a drop of $20 \mu \mathrm{L}$ of semen on a preheated slide, observed on using microscopy with a total increase of $40 \mathrm{x}$, receiving a score from 0 to $5(0$, ejaculated with absence of waves and 5 , presence of many sperm waves, moving rapidly), according to $[6,17]$.

The sperm concentration was made by counting in a Neubauer haematimetric chamber under light microscopy. The total number of spermatozoa was given in millions of cells per $\mathrm{mL}[6,17]$.

The sperm motility was evaluated by optical microscopy, with a total increase of $40 \mathrm{x}$. Each $10 \mu \mathrm{L}$ sample of semen was deposited on a pre-heated blade and cover slip. The results were expressed as percentage of cells with progressive motility. While vigour was evaluated on the same slide on which motility was assessed, under the same magnification. Their evaluation was given in a scale ranging from 0 to $5(0$ : absence or weak sperm movement up to 5: strong movement), according to $[6,17]$.

To evaluate sperm morphology, the semen samples were fixed in a buffered formalin solution and evaluated in the preparation of a conventional wet drop, observed under phase contrast microscopy, with a total increase of 1000x (Leitz, Germany). 200 spermatozoa per sample were counted and classified, with structural defects expressed as percentages of minor defects, major defects, and total defects $[6,17,18]$.

The integrity of the sperm plasma membrane was also evaluated by the hyposmotic test, according to $[19,20]$. The hyposmotic solution was prepared with $0.735 \mathrm{~g}$ of sodium citrate and $1.351 \mathrm{~g}$ of fructose for $100 \mathrm{~mL}$ of distilled water (osmotic pressure of $190 \mathrm{mOsm} \mathrm{kg-1).} \mathrm{Samples} \mathrm{for}$ evaluation were prepared by adding $50 \mu \mathrm{L}$ of semen to 500 $\mu \mathrm{L}$ of hyposmotic solution. Then, the samples were incubated at $37^{\circ} \mathrm{C}$ for 30 minutes. After incubation, a $10 \mu \mathrm{L}$ of each sample was examined under a phase contrast microscope, under a total magnification of $1000 \times$. Two hundred spermatozoa were counted and classified, so that changes (curvatures) in the tail of the spermatozoa after the test indicated that the cell had a normal plasma membrane, which was considered to be completely functional from the functional point of view. Already the spermatozoa that did not present curvature in the tail were considered as having a damaged plasma membrane.

\subsection{Statistical Analysis}

The meteorological data were evaluated using the general linear model (GLM), where as semen and sperm data were examined using the repeated measures statement of the MIXED procedure (Proc MIXED) of the Statistical Analysis Systems software (SAS Institute Inc., Cary, NC, USA). The model included the fixed effects of season. A Generalized Estimation Equation GEE test was used to determine differences between colour and aspect variables. The differences were considered to be statistically significant at $\mathrm{P}$ $<0.05$. Meteorological variables were tested for normality with Shapiro-Wilk test, and if data were not normal the Kruskal-Wallis test was performed.

\section{Results}

The meteorological data obtained for the environmental conditions - air temperature, relative air humidity, solar radiation and rainfall are presented in Table 1. They differ statistically in the two periods (RS and nRS).

Table 1. Meteorological variables in Santarém, municipality Pará state, between March and November 2016 (mean \pm SD). The rainy season: March - June; Non-rainy season: July to November 2016.

\begin{tabular}{|c|c|c|c|c|c|}
\hline Season & Temperature $\left({ }^{\circ} \mathrm{C}\right)$ & Relative humidity (\%) & Rainfall (mm) & Solar radiation $\left(w \cdot m^{-2}\right)$ & Wind speedy $\left(\mathrm{m}^{-1} \mathrm{~s}^{-1}\right)$ \\
\hline Rainy season & $28.1 \pm 1.8^{\mathrm{a}}$ & $89.4 \pm 10.2^{\mathrm{a}}$ & $2.418 \pm 309^{a}$ & $232.7 \pm 301.3^{\mathrm{a}}$ & $1.6 \pm 0.7^{\mathrm{a}}$ \\
\hline Non rainy season & $29.4 \pm 1.9^{b}$ & $79.0 \pm 10.6^{\mathrm{b}}$ & $381 \pm 95^{\mathrm{b}}$ & $260.6 \pm 314.0^{\mathrm{b}}$ & $2.0 \pm 1.0^{\mathrm{b}}$ \\
\hline
\end{tabular}

a, b Means with different superscripts within a column indicate significant differences within variables $(P<0,005)$.

The physical and morphological characteristics of buffalo bull semen through the rainy season (RS), corresponding to volume, colour, aspect, mass activity (swirling), progressive motility, vigour, concentration, sperm morphology and plasma membrane integrity of the ejaculates are described in
Table 2.

No statistical differences were detected regarding the quantity and quality of the different parameters of ejaculates, in the RS. All ejaculates were within the normal patterns described for the species, according to $[6,17]$. The physical 
and morphological characteristics of buffalo semen in the non-rainy period (nRS), corresponding to volume, colour, appearance, swirling, progressive motility, vigour, concentration, sperm morphology and plasma membrane integrity of the ejaculates are shown in Table 2.

Table 2. Average physical and morphological characteristics of buffalo ejaculates, in the rainy season (March to May) and non-rainy (August to November) $(n=100)$. Santarém, municipality, Pará state, 2016.

\begin{tabular}{lll}
\hline Seminal parameters & $\begin{array}{l}\text { Rainy season } \\
\text { (RS) }\end{array}$ & $\begin{array}{l}\text { Non rainy season } \\
\text { (nRS) }\end{array}$ \\
\hline Volume (ml) & $3.4 \pm 2.0^{\mathrm{a}}$ & $4.0 \pm 2.1^{\mathrm{a}}$ \\
Mass activity (0-5) & $4.4 \pm 0.5^{\mathrm{a}}$ & $3.0 \pm 1.0^{\mathrm{b}}$ \\
(Swirling) & $80.4 \pm 5.6^{\mathrm{a}}$ & $56.2 \pm 13.4^{\mathrm{b}}$ \\
Motilility (\%) & $4.4 \pm 0.4^{\mathrm{a}}$ & $3.0 \pm 1.0^{\mathrm{b}}$ \\
Vigour (0-5) & $657.300 \pm 237.865^{\mathrm{a}}$ & $586.000 \pm 291.925^{\mathrm{a}}$ \\
Concentration (x10 $\mathrm{sptz} / \mathrm{mL})$ & $9.0 \pm 2.6^{\mathrm{a}}$ & $20.8 \pm 9.9^{\mathrm{b}}$ \\
Major defects (\%) & $11.2 \pm 3.9^{\mathrm{a}}$ & $27.5 \pm 6.3^{\mathrm{b}}$ \\
Minor defects (\%) & $20.2 \pm 5.3^{\mathrm{a}}$ & $48.3 \pm 9.3^{\mathrm{b}}$ \\
Total defects(\%) & $84.8 \pm 5.6^{\mathrm{a}}$ & $57.9 \pm 12.4^{\mathrm{b}}$ \\
Plasma membrane integrity & & \\
(Hyposmotic test) (\%) & & \\
\hline
\end{tabular}

a, b Means with different superscripts within a row were significantly different between seasons $(P<0,005)$.

With reference to the colour parameter of the ejaculates, the shades were yellowish, white, yellowish-white and whitemarbled, while to the aspect were observed the aqueous, serous and milky characteristics. Mean volumes in the RS and $n R S$ were $3.4 \pm 2.0$ and $4.0 \pm 2.1$, respectively.

The data on concentration, colour, appearance and volume did not present statistical differences between the periods. The relative values for the mean concentration in $\mathrm{RS}$ and nRS were $657.300 \pm 237.865$ and 586.000 \pm 291.925 , respectively.

The wave motion, motility, vigor, major defects, minor defects, total defects and plasma membrane integrity showed a statistically significant difference between both periods $(\mathrm{P}<0.05)$.

The mass activity parameter (swirling) in RS and nRS, varied from 3 to 5 , with a mean of $4.4 \pm 0.5$ and of 1 to 5 , with an average of $3.0 \pm 1.0$, respectively, However, there was no statistical variation between the animals in these periods, but a statistical difference between the two periods (RS and nRS) occurred.

Progressive sperm motility presented a decrease in the values during the different phases of the experiment. The progressive motility of the semen in natura ranged from $70 \%$ to $95 \%$, with a mean of $80.4 \pm 5.6 \%$ in RS and decreased in $\mathrm{nRS}$, with collections varying from $20 \%$ to $75 \%$, but with a mean of $56.2 \pm 13.4 \%$.

Vigor, in both RS and nRS, in in natura semen it ranged from 4 to 5 , with a mean of $4.4 \pm 0.4$ and 2 to 5 , with a mean of $3.5 \pm 0.6$, respectively.

For larger defects between RS and nRS, the mean data were $9.0 \pm 2.6 \%$, ranging from 1.5 to $15.0 \%$ and $20.8 \pm$ $9.9 \%$, ranging from 10.5 to $50.5 \%$, respectively. For minor defects between RS and nRS, mean data were $11.2 \pm 3.9 \%$, with values obtained between 3.4 and $24.0 \%$ and mean values of $27.5 \pm 6.3 \%$, ranging from 15.5 to $54,5 \%$, respectively. For total defects, the mean values obtained were $20.2 \pm 5.3 \%$ for RS, ranging from 7.0 to $32.5 \%$; and mean data of $48.3 \pm 9.3 \%$ in nRS ranged from 32.5 to $76.5 \%$.

With respect to plasma membrane integrity, data on for the RS were $84.8 \pm 5.6 \%$, ranging from 69.5 to $92.5 \%$, in the nRS the average was $57.9 \pm 12.4 \%$, with a range of 16.0 to $91.5 \%$.

In Table 4, in the RS the obtained seminal analyzes showed ejaculates with volume of $3.4 \pm 2.0 \mathrm{~mL}$, swirling of $4.4 \pm 0.5$, motility of $80.4 \pm 5.6 \%$, Of $4.4 \pm 0.4$, concentration of $657.300 \pm 237.865,1 \times 10^{6} \mathrm{sptz} / \mathrm{mL}$, major defects $9.0 \pm 2.6 \%$, minor defects $11.2 \pm 3.9 \%$, total defects $20.2 \pm 5,3 \%$ and membrane integrity $84.8 \pm 5.6 \%$, whereas in the nRS, the results were $4.0 \pm 2.1 \mathrm{~mL}$, swirling $3.0 \pm 1.0$, motility of $56.2 \pm 13.4 \%$, vigour of $3.0 \pm 1.0$, concentration Of $586.000 \pm 291.925 .9 \times 10^{6} \mathrm{sptz} / \mathrm{mL}$, major defects $20.8 \pm$ $9.9 \%$, minor defects $27.5 \pm 6.3 \%$, total defects $48.3 \pm 9.3 \%$, and plasma membrane integrity of $57,9 \pm 12.4 \%$.

\section{Discussion}

The analysis of the results in Tables 2, 3 and 4, are in agreement with the data of [3] that reported ejaculates with better reproductive characteristics in periods of milder temperatures of the year. They also concluded that in warmer months the ejaculates are negatively affected in several characteristics.

In experiment [9], in Thailand (tropical climate), semen collections were performed between winter and spring, when temperatures were mild. For buffaloes, this period was considered more suitable for the collection of semen, destined for freezing, since the ejaculates collected during these months of the year presented higher membrane integrity and stability, as well as better values for the movement (speed) patterns provided by CASA (computerassisted sperm analysis) to the samples which were thawed, and no effect was observed on the quality of the ejaculates. The same authors did not observe significant differences in seminal characteristics in the different seasonal periods in ejaculates of buffalo bulls, with the exception of tail defects (morphology), which increased in the months of higher temperatures. Differently from what occurred in the present experiment, there were significant statistical differences for motility, vigour, mass activity, plasma membrane integrity, major defects, minor defects, and total defects $[1,4,5,6]$.

Hence, the photoperiod is an important factor that influences the seminal characteristics of buffaloes [13] and the influence of the humid tropical Amazonian environment on the reproduction and sexual activity of buffalo bulls has previously been reported, not only affecting the libido but also on the quality of fresh and freezing of semen [1]. Thus, the results found by these authors corroborate the data found in the present research, in which the environment influences the seminal characteristics in buffaloes

In adult buffaloes, there is a variation of seminal quality as a function of the time of year, which can be attributed, 
mainly, to an effect of the temperature of the environment on the animal and, consequently, on the spermatogenesis. The authors in [21], reported that during the summer months the percentage of live spermatozoa in ejaculates of adult buffaloes is $64.6 \pm 4.4 \%$, much lower than the data obtained in autumn, winter and spring, when they obtained values of $90.5 \pm 0.8 \%, 84.5 \pm 2.3 \%$ and $95.7 \pm 1.5 \%$, respectively.

On the other hand evaluation of the semen characteristics of zebu (Bos indicus) bull and buffalo bulls ejaculates kept at an artificial insemination center in Pará, in the Brazilian humid tropics showed also differences between RS and nRS [22]. In order to carry out the comparison, the data of six consecutive years on ejaculates collected during the most rainy season of the year (January to June) and during the least rainy season (July to December) were grouped. The buffalo bulls showed differences in seminal quality, always favourable for the ejaculates produced in the RS of the year. Sperm motility was the attribute that presented differences, both in the in natura semen $(74.20 \pm 9.87 \%$ versus $70.17 \pm$ $9.89 \%)$, and after the dilution $(75.62 \pm 6.95 \%$ versus $73.12 \pm$ $8.17 \%)$ and after thawing $(54.50 \pm 9.68 \%$ versus $49.30 \pm$ $10.74 \%$ ). No differences were observed between seasons for the characteristics of seminal volume, sperm concentration, mass activity, vigour and sperm defects (major, minor and total). In the present experiment, there was no significant statistical difference for volume, colour, appearance and sperm concentration.

Thus, it can be stated that the periods of the year influenced the seminal characteristics, since in the phase of better thermal comfort, the seminal quality was superior. Warmer months had a negative effect on seminal quality, where as in the same animals, in rainy months, they had better seminal characteristics, as was observed in the present work.

Even though in the temperate regions of the world, it was found that semen is of better quality during winter and spring than in summer and fall $[23,24]$, in tropical regions, semen quality was considered satisfactory during the RS. In the hot and humid tropical region of the Amazon, the best time for semen harvesting and processing is between January and June [6], which corresponds to the rainy season. Because buffaloes are very sensitive to thermal stress, it is natural they experience a decline in the quality of ejaculates, and is therefore a common finding during hot seasons of the year.

The management of buffaloes, including feed and facilities, as well as the age of the male, also have influence on semen production and quality [25]. The best-quality semen with respect to sperm morphology was observed in Murrah breed bulls aged 3 to 5 years $[25,26]$ and in NiliRavi breed buffalo bulls [27].

Therefore, in the humid tropical Amazonian region, the best time for processing semen for deep freezing is during the rainy season, although such practice can also be used throughout the year since improved management techniques are used to protect the buffalo donors, and these consist of keeping the animals in a shady environment and receiving baths during the hottest hours of the day $[1,4,5,6]$.
In the present work, the results for in natura semen are in accordance with the characteristics of normality described for buffalo semen described by [6, 16, 17], after collection by artificial vagina, with a minimum volume of $3 \mathrm{~mL}$, minimum vigour of 3 , motility higher than $70 \%$, plasma membrane integrity above $70 \%$ and total defects not greater than $30 \%$, obtained during the RS of the present experiment.

According to Vale $[6,16]$, a good quality buffalo ejaculate presents volume ranging from 1.0 to more than $3.0 \mathrm{~mL}$, sperm concentration of 600 to 1.200 million sperm per $\mathrm{mL}$ [12], minimum swirl of 3 (scale from 0 to 5), sperm motility between 60 and $80 \%$, vigor of at least 3 (scale from 0 to 5) and $\mathrm{pH}$ between 6.5 and 7.2; a similar data were obtained in the RS of the present experiment. The authors in [28] mentions that the minimum standards for the classification of a "probably fertile" sample of buffalo semen are: 500 million spermatozoa per $\mathrm{mL}$, more than $60 \%$ mobile spermatozoa with rectilinear progression and more than $70 \%$ spermatozoa with normal morphology.

Notwithstanding, to some authors [6, 16, 29, 30, 31] they agree that the volume of buffalo semen varies from 2 to $3 \mathrm{ml}$ for young animals in the age group of two to three years and from 4 to $6 \mathrm{ml}$ for animals above of four years, with concentration varying from 0.8 to $1.5 \times 10^{9}$ spermatozoa / $\mathrm{ml}$ and motility of $70-80 \%$, aspects also observed in the present study.

Some authors stated that colour of the normal buffalo ejaculate is milky-white to grayish, and volume rarely exceeding $5 \mathrm{~mL}$, as [32]. The same authors note that the sperm concentration is between 300 and 1.500 million cells per $\mathrm{mL}$, aspects which are in accordance with the results here obtained.

The mean progressive motility data of the in natura semen obtained in this study were higher than those described by [28], which reported an average value of $75.0 \%$. They were also superior to the desirable minimum parameters recommended by the CBRA (2013) for in natura semen, that is, progressive motility of $70 \%$, vigour 3 , swirling 3 and total of abnormal spermatozoids of $30 \%$, although these parameters are extrapolated from the bovine species to buffalo. The excellent indicators observed in the in natura semen in the present study seem to be related, among other aspects, to the experimental rigor used in the selection of donor bulls and their ejaculates.

As the nRS negatively influences the seminal quality, during this period managers should seek to improve the thermal comfort of the animals if they plan to use them in programs of semen collection, or for freezing.

\section{Conclusion}

In the mesoregion of the Lower Amazon, the ideal period for experiments using buffalo ejaculates are the rainy season months. For in this period a better quality in the ejaculate of buffaloes was observed.

The hypothesis of this work was validated a reproductive 
parameters of buffalo semen, such as whirling, motility, vigor, major defects, minor defects, total defects and plasma membrane integrity were better in the rainy period than in the non-rainy period, presenting a significant difference between the periods.

On the basis of the results discussed, in the regions where the tropical temperature predominates, as in the Amazon Region, with a humid tropical climate, suggest a special management needs to be implemented. Thus, recommended that animals have access to daily baths, especially during warmer times, so that they can dissipate body heat from metabolism and that caused by the environment. By being more sensitive to heat, special attention is given by an animal subjected to a semen harvest during a warmer time of the year. It is very important to protect animals against thermal stress, providing free access to the bath and shade, since this species has greater difficulty to dissipate body heat, and therefore a thermoregulatory system less efficient when compared to cattle.

\section{References}

[1] Vale, W. G. (2007). Effects of environment on buffalo reproduction, Italian Journal of Animal Science, 6: sup 2, 130142.

[2] Sharma, L., Pandey, V., Nigam, R., Singh, P., Saxena, A., and Swain, D. K. (2014). Seasonal variations in seminal plasma proteins of buffalo. Reproduction in Domestic Animals, 49 (3), 387-391.

[3] Bhakat, M., Mohanty, T. K., Gupta, A. K., Prasad, S., Chakravarty, A. K., and Khan, H. M. (2015). Effect of season on semen quality parameters in Murrah buffalo bulls. Buffalo Bulletin, 34 (1), 100-112.

[4] Titto, E. A. L., Russo, H. G., Lima, C. G. (1997). Efeito do banho de água sobre o conforto térmico de bubalinos. In: Congresso de Zootecnia, 6, 1997, Lisboa. Actas... Lisboa: APEZ (1): 15-18.

[5] Garcia, A. R. (2013). Conforto térmico na reprodução de bubalinos criados em condições tropicais. Revista Brasileira de Reprodução Animal, 37 (2): 121-130.

[6] Vale, W. G.(1994). Collection, processing and deep freezing of buffalo semen. Buffalo Journal, suppl. 2: 65-81.

[7] Squires, E. J. (2003). Applied animal endocrinology. Walingford: CABI Publishing. pp. 192-229.

[8] Garcia. A. R. (2006). Influência de fatores ambientais sobre as características reprodutivas de búfalos do rio (Bubalus bubalis) Revista de Ciências Agrárias no 45. Suppl.

[9] Koonjaenak, S., Chanatinart, V., Aiumlamai, S., Pinyopumimintr, T., and Rodriguez - Martinez, H. (2007). Seasonal variation in semen quality of swamp buffalo bulls (Bubalus bubalis) in Thailand. Asian journal of andrology, 9 (1), 92-101.

[10] Phogat, J. B., Pandey, A. K., Singh, I. (2016). Seasonality in buffaloes reproduction. International Journal of Plant, Animal and Environmental Sciences, 6(2): 46-54.
[11] Marai, I. F. M., Haeeb, A. A. M. (2010). Buffalo's biological functions as affected by heat stress - a review. Livestock Science, 127 , p. 89-109.

[12] Vale, W. G. (2011). Avances biotecnológicos em reproduccíon de búfalos. Tecnología em marcha. v. 24 (5): 89-104.

[13] Sansone, G., Nastri, M. J. F., Fabbrocini, A. (2000). Storage of buffalo (Bubalus bubalis) semen. Animal reproduction science, 62 (1): 55-76.

[14] Ohashi, O. M., Santos, S. S. D., Miranda, M. S., Cordeiro, M. S., Costa, N. N., and Silva, T. V. G. (2011). Morfologia do sistema genital, distúrbio reprodutivo e manejo do macho bubalino (Bubalus bubalis). Revista Brasileira de Reprodução Animal, Belo Horizonte, 35 (2): 88-94.

[15] Souza, I. M. P., Costa, A. C. L., Silva Junior, J. A., Feitosa, J. R. P. (2011). Estudo do conforto térmico em cidades de diferentes dimensões no estado do Pará. In: Congresso Brasileiro de Agrometeorologia, 17, 2011, Guarapari, ES. Actas... Guarapari: SESC (1): 1-5.

[16] VALE, W. G. (2002). Reproductive management of buffalo male aimming semen production for artificial insemination. In: Buffalo Symposium of Americas, 1, Belém, PA, 2002. Proceedings ... Belém: APCB. pp. 156-171.

[17] CBRA - Colégio Brasileiro Reprodução Animal (2013). Manual para exame andrológico e avaliação de sêmen animal. 3a ed. Belo Horizonte: CBRA. pp. 104.

[18] Blom, E. (1973). The ultrastructure of some characteristic sperm defects and a proposal for a new classification on the bull spermiogram. Nord. Veterinaermed., 25: 383-391.

[19] Rasul, Z.; Anzar, M.; Jalali, S.; Ahmad, N. (2000). Effect of buffering systems on post-thaw motion characteristics, plasma membrane integrity, and acrosome morphology of buffalo spermatozoa. Animal Reproduction Science, 59: 31-41.

[20] Barros, P. M. H., Nichi, M., Cortada, C. N. M., Carvalho, N. A. T., Baruselli, P. S., Barnabe, R. C., Barnabe, V. H. (2007). Semen evaluation of Murrah buffalo bulls using sperm functional tests. In: World Buffalo Congress, 8 (6) CasertaItália. Proceedings... Caserta, 2007, pp. 772-774.

[21] Gangwar, P. C. (1980). Climate and reproduction in buffaloes - a review. The indian journal of dairy science, 33: 419-426.

[22] Coimbra, A. S. (2002). Características seminais de touros bovinos zebuínos (Bos taurus indicus), taurinos (Bos taurus taurus) e bubalinos (Bubalus bubalis), doadores de sêmen em condições de trópico úmido amazônico. 78f. Dissertação (Mestrado) Universidade Federal do Pará, Belém-PA, Brasil.

[23] Galli, A., Bornaghi, V., Balduzzi, D., Buttazzoni, L., Aleandri, R., (1993). Sexual behaviour and semen quality relating to italian buffalo. Proc. 3rd World Buffalo Congr., Varna, Bulgaria (1) pp. 562-570.

[24] Mohan, G., Sahni, K. L., (1990). Efficiency of semen production in buffalo bulls. In: Acharya, R. M., Lokeshwar, R. R., Kumar, S. Eds.., Recent Advances in Buffalo Research (3) pp. 14-16.

[25] Chinnaiya, G. P., Ganguli, N. C., (1990). Effect of age and season on the initial attributes and preservability of buffalo bull semen. In: Acharya, R. M., Lokeshwar, R. R., Kumar, S. _Eds.., Recent Advances in Buffalo Research (3) pp. 80-86. 
[26] Kumar, S., Sahni, K. L., Mohan, G. (1994). Effect of yolk, glycerol and sugars on post-thaw survival of buffalo spermatozoa in TRIS dilutor. Indian Journal Animal Science, New Delhi, v. 64 (4): 362. 364.

[27] Saeed, A., Chaudhry, R. A., Khan, I. H., Khan, N. U. (1990). Morphology of semen buffalo bulls of different age groups, in: R. M. Acharya, R. R. Lokeshwar, S. Kumar (Eds.), Recent Advances in Buffalo Research, vol. 3, pp. 17-19.

[28] Barnabe, V. H. (1999). Colheita e avaliação o sêmen de búfalos. In: Simpósio Paulista de Bubalinocultura, 1, Jaboticabal, Brasil. Anais... Jaboticabal: Funep. pp. 122-125.

[29] Javed, M. T., Khan, A., Kausar, R. (2000). Effect of age and season on some semen parameters of Nili-Ravi buffalo (Bubalus bubalis) bulls. Veterinarski Arhiv, v. 70, n. 2: 83-94.
[30] Pant, H. C., Sharma, R. K., Patel, S. H., Shukla, H. R., Mittal, A. K., Kasiraj, R., Misra, A. K., Prabhakar. (2003). Testicular development and its relationship to semen production in murrah buffalo bulls. Theriogenology, v. 60: 27-34.

[31] Ohashi, O. M.; Baruselli, P. S. Biotécnicas da reprodução animal aplicadas em bubalinos. In: Biotécnica aplicadas à Reprodução Animal. 2. ed. São Paulo: Roca, 2008. pp. 105123.

[32] Jainudeen, M. R., Hafez, E. S. E. (2004). Bovinos e Bubalinos. In: Hafez, ESE, Hafez, B. Reprodução Animal. Barueri, Brasil: Manole. pp. 159-171.

[33] Rafidah, O., Zuki, A. B., Azhar, K., Zamri-Saad, M. (2014). Improving the reproductive performance of buffaloes in Sabah, Malaysia. Journal of Animal Health and Production, v. 2, 1: 1-4. 